Anna Jurkowska-Zeidler

\title{
THE REGULATION OF THE SINGLE FINANCIAL MARKET IN THE EUROPEAN UNION. A NEW DIMENSION
}

\section{Background}

Financial markets are crucial to the functioning of modern economies. The more integrated they are, the more capable and effective the allocation of capital will be. Therefore the single financial market is a fundamental part of the European Union (EU) purpose of achieving more and better jobs in a more dynamic and inventive Europe. Completing the single market in financial services is more and more recognized as one of the key areas for EU future growth, essential for the European Union global competitiveness and thus a crucial part of the Lisbon economic reform process.

Over the past couple of decades we have witnessed a rapid expansion and integration of financial markets - both in the EU and globally. Financial markets are becoming ever more important for economic development. Their quality is a critical determinant of countries' economic stability and of their success in a world of financial globalization. Financial markets development and legal regulatory framework are so closely connected as to be part of a single phenomenon. The marketplace changes would not have occurred without the regulatory developments but, on the other side, the regulatory changes have helped to remove barriers to the cross-border provision of services and created conditions for integration of financial markets.

The financial services sector includes three major areas for which similar EU regulation apply notably banking services, insurance services and capital market (investment services and securities) and also investment funds, financial markets 
infrastructure (such as well-functioning cross-border clearing and settlement processes), retail financial services and payment systems. ${ }^{1}$

It had been comprehensible for some time that the increasing size and sophistication of financial markets was becoming a huge challenge for existing framework for financial regulation and supervision. For that reason at the global level, EU financial market regulation in terms of safe and stability is being coordinated and synchronized with the relevant organizations - the Financial Stability Forum, the International Monetary Fund, G-10 Basel Committee on Banking Supervision etc.

\section{The Single European Financial Market}

There is no widely accepted definition of financial integration. Generally, a perfectly integrated market is regarded as a market where prices for similar products and services converge across geographical borders. An integrated market should enable all market participants to buy and sell financial services, which share the same characteristics, under the same conditions, regardless of the location of origin of the participant. ${ }^{2}$

Financial integration can be also described as an absence of obstacles to significant cross-border activities and to enterprises in their access to, or in their ability to supply, financial services and products, in particular with respect to their geographic location. The general objective of the single market is to remove all public policy/regulatory obstacles to the free movement of goods, services, persons and capital. ${ }^{3}$

Europe has made considerable progress in creating a single market for financial services. There is no doubt that the European Monetary Union has been the catalyst for the renewed attention given in recent years to the challenges of financial integration. ${ }^{4}$ The Single European Market stands for "free movement" of people, goods, services, and capital. ${ }^{5}$ For financial services the principles of freedom of establishment and free movement of services have been clarified and developed

\footnotetext{
1 Detailed information on these subjects see EU general financial services policy issues see http://ec.europa.eu/ internal_market/finances/index_en.htm

2 European Financial Integration Report 2007, Commission Staff Working Document, Brussels, 10.12.2007, SEC(2007) 1696, p. 8; http://ec.europa.eu/internal_market/finances/docs/cross-sector/fin-integration/efir_report_ 2007_en.pdf

3 Report from the EU Financial Services Committee (FSC) on Financial Integration, FSC 4156/04, Brussels 17 May 2004, See R. M. Lastra, Legal Foundations of International Monetary Stability, Oxford University Press 2006, p. 321.

4 See C. Kosikowski, Prawo Finansowe w Unii Europejskiej, Oficyna Wydawnicza Branta, Bydgoszcz-Warszawa 2008, p. 206.

5 About EU single market general policy framework see http://ec.europa.eu/internal_market/index_en.htm
} 
over the years through the case law of the European Court of Justice. In addition, significant developments and progress in the field of financial services have been brought about through specific legislation in this field.

\section{History of the legislative process to adopt regulation of the EU financial market}

The goal of creating an internal market in financial services was given fresh impetus with the 1985 White Paper on the Internal Market ${ }^{6}$ and 1986 Single European Act. ${ }^{7}$ The new strategy was based on the generalization of the concept of mutual recognition on the basis of prior minimum harmonization, the principle of "single passport" and the rule of home country control. ${ }^{8}$ However, maximum harmonization is inconsistent with the fundamental Single Market principles of minimal harmonization and mutual recognition nowadays, in some directives the use of maximum harmonization as a method of integration through law. ${ }^{9}$ is noticed. With this approach, EU Member States cannot introduce additional requirements other than those specified in the directive.

The principles of mutual recognition and the "single passport" allow financial institutions legally established in one EU Member State to establish/provide their services in the other Member States without further authorization requirements. These principles are essential for financial stability in the EU and require the establishment of a common framework ensuring prudential supervision and consumer protection all over the European Single Financial Market.

Directives became the preferred legislative measure for achieving financial integration in the European Union. ${ }^{10}$ They regulate the initial and on-going conditions for financial service providers (banks, insurers, investment firms, investment funds), establish requirements for the providing financial services, enact a prudential norms and capital adequacy norms. The conditions for the setting-up of financial institutions and their on-going business are similar in individual sectors of financial market, but specially provide for a level playing field between non-bank investment firms and banks providing investment services. ${ }^{11}$

6 Completing the Internal Market: White Paper from the Commission to the European Council, Milan, 28-29 June 1985, COM(85) 310, June 1985; http://europa.eu/documents/comm/white_papers/pdf/com1985_0310_f_en.pdf Single European Act of 28 February 1986 (entry into force 1.7.1987); OJ L 169, 29. 6. 1987.

See J. Steiner, L. Woods, Textbook on EC Law, Fifth Edition, London 1996 p. 294

Maximum harmonization was used, for example, in Directive 2002/65/EC of the European Parliament and of the Council of 23 September 2002 concerning the distance marketing of consumer financial services, OJ L 271, 9.10.2002.

10 See A. Jurkowska-Zeidler, Bezpieczeństwo rynku finansowego w świetle prawa Unii Europejskiej, Wolters Kluwer, Warszawa 2008, pp. 136-151.

11 About Acquis communautaire in the field of financial services See Finanse, seria Acquis communautaire, ed. Z. Brodecki, LexisNexis, Warszawa 2004 
From 1999 to 2005, this overarching EU policy to improve the Single Market for financial services was delivered in the framework of the Financial Services Action Plan (FSAP). ${ }^{12}$ The Action Plan identified a range of issues calling for urgent action to secure the full benefits of the single currency euro and an optimally functioning Single European Financial Market.

The FSAP suggested indicative priorities and time-scales for legislative measures to tackle three strategic objectives: ensuring a Single Market for wholesale financial services, developing open and secure markets for retail financial services and ensuring the continued stability of the EU financial market through the established state-ofthe-art prudential rules and supervision. ${ }^{13}$ So essentially the action was envisaged under three headings: wholesale markets, retail markets, and sound supervisory structures. The Action Plan also addressed broader issues concerning an optimal EU Single Financial Market, including the elimination of tax obstacles to financial market integration.

Although progress has been made through the successful completion of the Financial Services Action Plan (FSAP), the Commission concluded that the EU financial services industry (banking, insurance, securities, asset management) still has a strong untapped economic and employment growth potential. So in December 2005, the Commission published the White Paper on Financial Services Policy 2005-2010, which sets out the Commission's objectives in financial services policy for the period to $2010 .{ }^{14}$ The Commission's new strategy explores the best ways to effectively deliver further benefits of financial integration to business and consumers alike. While the FSAP focused mainly on the wholesale market, retail integration became more important over the next period provided in the White Paper.

The objectives of the Commission's financial services policy over the 20052010 years are:

1. dynamic consolidation of financial services, towards an integrated, open, inclusive, competitive, and economically efficient EU financial market;

2. better regulation - implement, enforce and continuously evaluate the existing legislation and to apply rigorously the better regulation plan for future initiatives; Brussels 28 October 1998; Financial Services - Implementing the Framework of Financial Markets: Action Plan, Commission Communication COM (1999) 232, 11.05.1999; http://ec.europa.eu/internal_market/finances/docs/ actionplan/index/action_en.pdf 
3. enhancing supervisory cooperation and convergence, deepen relations with other global financial marketplaces and strengthen European influence globally

4. removing the remaining economically significant barriers so financial services can be provided and capital can circulate freely throughout the EU at the lowest possible cost - with effective levels of prudential and conduct of business regulation, resulting in high levels of financial stability, consumer benefits and consumer protection;

Both the Financial Services Action Plan and the White Paper on Financial Services Policy are important initiatives in the field of EU financial market integration but they do not change the current financial supervisory structure, which is a crucial element of the Safety Net of the EU Single Financial Market. The home country supervision principle, underpinned by mutual recognition, and separation, decentralization, segmentation, cooperation are the core of the supervisory architecture in the European Union. ${ }^{15}$

\section{The Lamfalussy Framework for financial market regulation and supervision in the EU}

The emerging European Financial Architecture is the result of the extension of the Lamfalussy Framework for the regulation of securities markets to banking and insurance. ${ }^{16}$ The major novelty of the Lamfalussy Procedure is its four-level regulatory approach, namely (1) framework principles, (2) implementing measures, (3) cooperation, (4) enforcement, whose aim is to accelerate the legislative process for the financial regulation in the EU. ${ }^{17}$ The main innovation is the distinction between "EU implementation" in level 2 (with new "Lamfalussy level 2 regulatory committees" established individually for securities, banking and insurance as well as for financial conglomerates) and "national implementation and cooperation" in level 3 (with "Lamfalussy level 3 supervisory committees" established for securities, banking and insurance). The level 2 and level 3 committees are a form of supervisory cooperation between competent authorities of EU Member States.

15 See A. Jurkowska, The institutional architecture of banking supervision in the European Union, [in:] Current questions of the efficiency of public finance, financial law and tax law in the countries of Central and Easter Europe, ed. M. Štrkolec, Univerzita Pavla Josefa Šafárika v Košiciach, Košice 2005 also See R. M. Lastra, The Governance Structure for Financial Regulation and Supervision in Europe, Columbia Journal of European Law, vol. 10, Issue 1, Fall 2003, p. 50.

16 Lamfalussy Report was published in February 2001 and adopted by the European Council in its Resolution of 23 March 2001; http://ec.europa.eu/internal_market/en/finances/general/lamfalussy.htm

17 For the strengths and weaknesses of the Lamfalussy Procedure see K. Lanoo, The Transformation of Financial Regulation and Supervision in the EU, [in:] Handbook of Central Banking and Financial Authorities in Europe, ed. D. Masciandaro, p. 490. 
Through the Level 3 committees more than 80 national supervisors in the EU have been brought together.

It should be emphasized that through the Lamfalussy approach started, as a "regulatory issue", it soon became a "supervisory" matter, leading to an overhaul of the institutional architecture of supervision in the European Union. ${ }^{18}$ Nevertheless, the Lamfalussy Procedure does not imply the centralization of supervisory and regulatory responsibilities. Hence there is no transfer of supervisory competencies from national to the supranational arena. Therefore, building the effective Financial Safety Net still remains at the national level.

\section{The Safety Net of the EU Single Financial Market}

The Financial Safety Net is widely defined as a set of procedures and facilities in place to protect stakeholders and society at large from loss should a financial institution fail or default. ${ }^{19}$ Therefore, the preservation of financial stability is the aim of the new financial architecture. The stability of financial market is an important global public good, so there is a strong need to build the Financial Safety Net as a system to prevent, manage and resolve financial crises. ${ }^{20}$

Since the subprime mortgage loans crisis in the United States in mid 2007, the European Union has been a key player in international efforts to bring financial stability back to the financial markets. ${ }^{21}$ In the future the EU needs particularly a refocusing of financial supervision to ensure better management of crisis situations and market problems of the scale we have been experiencing over the past period.

In October $2007 \mathrm{EU}$ finance ministers agreed on a 15 month "roadmap" to examine whether financial rules need to be changed in order to improve the way cross-border banking crises are handled in the future and avoid a repeat of this market turmoil following the US subprime mortgage crisis. ${ }^{22} \mathrm{EU}$ roadmap to get out of the turmoil combines actions of a regulatory and non-regulatory nature which are structured around four main objectives notably enhancing transparency in the market, especially relating to complex financial instruments; improving the

18 R. M. Lastra, Legal Foundations..., p. 321

19 D. G. Mayes, The Role Of The Safety Net In Resolving Large Financial Institutions, IADI 4th Annual Conference "Challenges for Deposit Insurers in Resolving Bank Failures", Taipei, Taiwan 28-29 September 2005; http://www. iadi.org/pastevents/.

20 More about architecture of the EU Financial Safety Net see A. Jurkowska-Zeidler, Bezpieczeństwo rynku finansowego..., pp. 193-207.

21 Financial markets across the globe went into a financial turmoil following the US subprime mortgage crisis in early August 2007, compelling the European Central Bank, the Bank of England and the US Federal Reserve to massively provide liquidity to keep the financial system repulsing a possible liquidity crisis.

22 Council Conclusions on enhancing the arrangements for financial stability in the EU, 2822nd Economic and Financial Affairs Council meeting, Luxembourg 9 October 2007; http://www.consilium.europa.eu/ueDocs/cms_ Data/docs/pressData/en/ecofin/96351.pdf 
way investments are valued, by agreeing on common standards; strengthening the prudential framework and supervisory mechanisms in banking sector, through better information-sharing between national authorities and the development of crossborder cooperation agreements, and; improving market functioning, with a particular focus on credit rating agencies. ${ }^{23} \mathrm{EU}$ ministers have also agreed on a Memorandum of Understanding (MoUs) which lays down how supervisory authorities, central banks and financial ministers from the twenty seven EU Member States should work together more closely and effectively when a systemic important cross-border bank is in trouble.

In the light of the agreements reached by the ECOFIN Council in October 2007, the Financial Supervisory Authorities, the Central Banks and the Finance Ministries of the European Union have agreed on a new Memorandum of Understanding on co-operation in financial crisis situations. ${ }^{24}$ The Memorandum took effect on 1 June 2008, included one hundred and eighteen signatories from twenty seven EU Member States and the ECB. The MoUs is designed to facilitate the management and resolution of cross-border systemic financial crises in a way that minimises the economic and social costs of a crisis, while promoting market discipline and limiting moral hazard effect. The Memorandum, defines practical procedures for the involvement of all relevant parties in a crisis situation, based on the existing legal responsibilities and built on existing networks of authorities. The document defines coordination mechanisms, including the identification of a national coordinating authority and a cross-border coordinating authority. As a rule, the cross-border coordinator is one of the authorities of a financial group's home-country.

The Signatories of the Memorandum agreed to follow a set of common principles in the management of any cross-border financial crisis, which involves at least one banking group which has substantial cross-border activities and is facing severe problems which are expected to trigger systemic effects in at least one EU Member State and is assessed to be at risk of becoming insolvent. These principles, set out in MoU, should be respected in the management of any cross-border financial crisis with potential systemic implications. The common principles include references to banks and banking groups, reflecting their specific role in the financial system. ${ }^{25}$

The new Memorandum extends the previous Memorandum signed in 2005 in two ways. Firstly, the Memorandum includes common principles on cross-border crisis management, a common framework for assessing the systemic implications

\footnotetext{
23 See article EU agrees roadmap to avert future financial turmoil, Wednesday 10 October 2007; http://www. euractiv.com/en/financial-services/eu-agrees-roadmap-avert-future-financial-turmoil/article-167508

24 Memorandum Of Understanding On Cooperation Between The Financial Supervisory Authorities, Central Banks And Finance Ministries Of The European Union On Cross-Border Financial Stability, Brussels 1 June 2008, ECFIN/CEFCPE(2008)REP/53106 REV REV; http://www.ecb.int/pub/pdf/other/mou-financialstability2008en.pdf 
of a financial crisis, and common practical guidelines for crisis management in line with the ECOFIN conclusions of 9 October 2007. Secondly, considering the increasing inter-linkages between financial sectors, the securities market, insurance and occupational pension, supervisors have agreed to join the new Memorandum, thereby acknowledging that the involvement of a broader range of authorities is necessary.

The creation of an agreement on common principles and practical arrangements to be applied in the case of cross-border financial crisis reflects the ongoing integration of financial markets and market infrastructures in the EU, the growing number of large financial institutions, more and more complicated structure of financial conglomerates, sophisticated financial instruments and the ensuing higher risk of cross-border contagion affecting more than one EU Member State.

In the legal context the Memorandum is a non-legally binding instrument for setting out practical arrangements aimed at promoting co-operation between authorities in crisis or potential crisis situations. The Memorandum is based on the current institutional and legislative framework and does not preclude any respective institutional responsibilities or restricting capacity of home state authorities, which are set out in national and Community legislation.

\section{Conclusions}

Financial integration in the European Union has progressed although the speed and scope of that process has not been the same across all market segments. It is crucial that the EU Single Financial Market delivers its full potential for consumers, in terms of a broad range of safe, competitive financial services, and for undertakings, in terms of easier and wide-ranging access to a deep and liquid market for investment capital.

I am confident that realization of the complete integration of financial market still will be accorded the highest political priority because of an extensive awareness of the huge potential benefits the EU Single Financial Market offers. In parallel there have been developments in the regulation and supervision of financial institutions in the EU. Therefore, in my opinion, this awareness stems notably from the introduction of the single currency euro and the gathering pace of adopting financial regulation dedicated to preserving and securing the stability of the Single European Financial Market.

It is obvious that financial stability in the EU is a common concern for all Member States and must be safeguarded on the basis of close cooperation. All agree with a suggestion that an integrated financial market requires a more integrated 
supervisory design, so that there must be strengthened cooperation and coordination at regional or pan-European level and convergence of supervisory practices.

Integration, internationalization, globalization, open financial markets and the challenges that come along with them, will remain a reality. The regulatory and supervisory EU authorities must learn how to manage; the European Financial Architecture needs comprehensive reform. In this respect, the latest financial crisis underlines more than ever how urgently major change of the existing EU supervisory structure is needed. The EU Financial Safety Net - framework for prudential supervision and crisis management and resolution - must allow a quick response to cross-border systemic financial crises and their implications. 


\section{Streszczenie}

W niniejszym artykule przeanalizowane zostały procesy i procedury implementacji finansowych regulacji w obszarze jednolitego rynku finansowego w Unii Europejskiej. Kształt obecnych przepisów dotyczących usług finansowych w UE opiera się na wzajemnej uznawalności na podstawie wcześniejszej harmonizacji, na zasadzie ,jednolitego paszportu” i regule kontroli krajowej. Jednakże Europejska Architektura Finansowa nie jest strukturą statyczną. Pojawia się szereg czynników, które wpływają na zmiany instutcjonalne jednolitego europejskiego rynku finansowego, w szczególności są to procesy ukierunkowane na ujednolicanie i konsolidację organów nadzorczych na poziomie krajowym (które mogą torować drogę do powstania jednolitej instytucji nadzorczej - Eurpejskiego Organu Usług Finansowych) oraz procesy ustanawiające efektywny system bezpieczeństwa jednolitego rynku finansowego UE. 